\title{
Ticks on pastures and on two breeds of cattle in the Eastern Cape province, South Africa
}

\author{
Authors: \\ Nkululeko Nyangiwe ${ }^{1}$ \\ Sindisile Goni ${ }^{1}$ \\ Louis P. Hervé-Claude 2 \\ Inga Ruddat ${ }^{2}$ \\ Ivan G. Horak ${ }^{3,4}$ \\ Affiliations: \\ ${ }^{1}$ Döhne Agricultural \\ Development Institute, \\ Stutterheim, South Africa \\ ${ }^{2}$ Institute of Biometry, \\ Epidemiology and \\ Information Processing, \\ University of Veterinary \\ Medicine of Hannover \\ Germany \\ ${ }^{3}$ Department of Veterinary \\ Tropical Diseases, University \\ of Pretoria, South Africa \\ ${ }^{4}$ Department of Zoology and \\ Entomology, University of the \\ Free State, South Africa \\ Correspondence to: \\ Ivan Horak \\ Email: \\ ivan.horak@up.ac.za \\ Postal address: \\ Private bag X04, \\ Onderstepoort 0110, \\ South Africa \\ Dates: \\ Received: 07 Feb. 2011 \\ Accepted: 14 May 2011 \\ Published: 07 Oct. 2011 \\ How to cite this article: \\ Nyangiwe, N., Goni, S., \\ Hervé-Claude, L.P., Ruddat, I. \\ \& Horak, I.G., 2011, 'Ticks on \\ pastures and on two breeds \\ of cattle in the Eastern Cape \\ province, South Africa', \\ Onderstepoort Journal \\ of Veterinary Research \\ 78(1), Art. \#320, 9 pages. \\ doi:10.4102/ojvr.v78i1.320
}

(C) 2011. The Authors.

Licensee: AOSIS

OpenJournals. This work

is licensed under the

Creative Commons

Attribution License.
Many studies on the population dynamics of questing ticks on pastures and of parasitic ticks on cattle have been conducted. Few, however, have attempted to link the two in a single study. This study aimed to assess the population dynamics of questing ixodid ticks on pastures and of adult ticks on two breeds of cattle with different levels of susceptibility to tick infestation on the same pastures. Between January 2005 and December 2009 questing ixodid ticks were collected monthly from natural pastures at the Döhne Agricultural Development Institute and at the adjacent Campagna Production System in the Amahlathi District, Eastern Cape province, South Africa. Between February 2007 and January 2010 adult ticks were collected monthly from Bonsmara and Nguni cattle grazing these pastures. Ten tick species were collected from the pastures and 12 from the cattle. Significantly more questing larvae of Rhipicephalus appendiculatus, Rhipicephalus decoloratus, Rhipicephalus evertsi evertsi and Rhipicephalus microplus were recovered from the pastures grazed by Bonsmara cattle than from those grazed by Nguni cattle $(p \leq 0.05)$. Significantly more adult Hyalomma rufipes, Rhipicephalus follis, $R$. appendiculatus, $R$. decoloratus, $R$. evertsi evertsi and R. microplus were collected from the Bonsmara cattle than from the Nguni cattle $(p \leq 0.05)$. The study showed that Nguni cattle are less susceptible to tick infestation than are Bonsmara cattle and fewer questing ticks are collected from pastures grazed by Nguni cattle than by Bonsmara cattle.

\section{Introduction}

At least 75 ixodid tick species are present in South Africa (Walker 1991), but only four of these are important vectors of disease in cattle. They are Amblyomma hebraeum, vector of Ehrlichia ruminantium, the causative organism of heartwater; Rhipicephalus appendiculatus, vector of Theileria parva, the causative organism of East Coast fever; Rhipicephalus decoloratus, vector of Babesia bigemina, the causative organism of African redwater; and Rhipicephalus microplus, vector of both Babesia bovis, the causative organism of Asiatic redwater, and B. bigemina (Norval \& Horak 2004). Amblyomma hebraeum, R. appendiculatus and R. decoloratus are indigenous to South Africa, whilst it is generally accepted that $R$. microplus was introduced into the country on cattle imported from Madagascar after the rinderpest epidemic (Hoogstraal 1956).

Some breeds of cattle, and specifically Nguni cattle, have the ability to acquire resistance to tick infestation (Spickett et al. 1989). The Döhne Agricultural Development Institute, which includes the adjacent Campagna Production System, Eastern Cape province, South Africa, has maintained separate herds of Bonsmara and Nguni cattle for several years. Both R. decoloratus and R. microplus are present on these animals. The set-up at the Döhne institute thus presents an excellent opportunity to compare the resistance of Bonsmara and Nguni cattle to natural tick infestations and to explore the dynamics of $R$. decoloratus and $R$. microplus, as well as other tick species, on these animals and on the pastures.

Our study had several objectives. Firstly, we aimed to establish the species composition of freeliving ticks questing for hosts on the pastures at Döhne and Campagna, and of adult ticks on cattle grazing the pastures at the two localities. Secondly, the study aimed to determine whether the number of questing ticks on the pastures grazed by Bonsmara cattle and the number of adult ticks on these animals differed from that on the pastures grazed by Nguni cattle and the number of adult ticks on the latter animals. Thirdly, we aimed to determine the seasonality of questing ticks on the pastures and of adult ticks on the cattle.

\section{Materials and methods}

The study was conducted at the Döhne Agricultural Development Institute (hereafter referred to as Döhne) and at the adjacent Campagna Production System (hereafter referred to as Campagna), both located in the Amahlathi District, Eastern Cape province. The term Döhne complex will 
be used when referring to both. Döhne $\left(32^{\circ} 31^{\prime} \mathrm{S}, 27^{\circ} 28^{\prime} \mathrm{E}\right)$ comprises an area of 992 ha and its vegetation is defined as Döhne Sourveld (Acocks 1988). The dominant grass species are Eragrostis curvula, Eragrostis plana, Sporobolus africanus and Themeda triandra. Campagna $\left(32^{\circ} 29^{\prime} \mathrm{S}, 27^{\circ} 29^{\prime} \mathrm{E}\right)$ is 248 ha in extent and its vegetation is characterised by an open, treed savanna with a moderate shrub and grass cover and is classified as Eastern Province Thornveld (Acocks 1988). In addition to the four major grass species at Döhne, the grazing on Campagna consists of Andropogon appendiculatus and Heteropogon contortus.

A herd of about 46 Bonsmara cattle, which included 16 replacement heifers, rotationally grazed five camps of natural veld at Döhne. The camps varied in size (from 12.7 ha to 17.0 ha), with a total surface area of 72 ha. A herd of about 64 Nguni cattle, of which 24 were replacement heifers, similarly grazed five camps of between 9.9 ha and 14.7 ha, with a total surface area of 65.3 ha. At Campagna a herd of approximately 30 Bonsmara cattle, of which seven were replacement heifers, rotationally grazed five camps of between 10.9 ha and 16.2 ha, with a total surface area of 69.4 ha. When grazing was inadequate the animals were fed lucerne hay and winter and summer licks were provided ad libitum. Because of a sudden spate of mortalities amongst the Bonsmara cattle a few years earlier, due probably to Babesia bovis infection, they were treated with the acaricide flumethrin (Drastic Deadline, Bayer Animal Health) at least once a month, administered as a pour-on. The Nguni cattle were treated only when adult ticks became visible.

Ten flannel strips $(100 \mathrm{~cm} \times 10 \mathrm{~cm})$ were attached next to each other on a $120-\mathrm{cm}$-long wooden spar with Velcro tape and the two ends of a twine harness were tied to the tips of the spar. An operator collected ticks questing for hosts from the vegetation by dragging the spar, using the twine harness, across the vegetation over a distance of $100 \mathrm{~m}$ (Spickett et al. 1992). Drags were always repeated six times at approximately 50 - $\mathrm{m}$ intervals in camps grazed by the respective cattle breeds. After each drag, the ticks on the flannel strips were collected using forceps and stored in 70\% ethanol in internally labelled glass vials. Drag-sampling of the vegetation was performed monthly between January 2005 and December 2009. With a few exceptions sampling was performed during the fourth week of each month so that it coincided with the weighing and dipping of the cattle grazing the pastures. Drags were not performed over dew-laden grass early in the morning or immediately after rain, as this would wet the flannel strips and decrease their efficacy for picking up questing ticks. During the five years of the study a total of 1080 drags were made and all the ticks collected were identified, classed by life stage and counted under a stereoscopic microscope. The aggregate numbers of larvae collected per month were used to illustrate graphically the seasonal abundance of the most numerous tick species.

From February 2007 to January 2010, adult ticks were collected monthly from one side (including half the head and one ear) and from the whole of the upper perineum and tail- brush of three Bonsmara and three Nguni cattle at Döhne and three Bonsmara cattle at Campagna. All the ticks collected were identified, classed by gender, and counted under a stereoscopic microscope. The aggregate numbers of adult ticks collected per month were used to illustrate graphically the seasonality of the most numerous species. Maximum and minimum atmospheric temperatures, rainfall and relative humidity were measured daily at Döhne.

The tick counts were entered into a Microsoft Excel database and all analyses were performed using SAS (SAS Institute Inc. 2006, Edition 9.1.3). Because the data were not normally distributed, owing to a large number of zero counts which makes log transformation in the search for normality unreliable, non-parametric tests (Kruskal-Wallis and Wilcoxon) were performed (Altman 1991) to determine significant differences between groups. The groups comprised ticks collected from Döhne pastures and Bonsmara cattle on these pastures, ticks from Döhne pastures and Nguni cattle on these pastures, and ticks from the pastures and Bonsmara cattle at Campagna. Analyses were performed for all species of questing and parasitic ticks whenever there were adequate numbers. A significance level of $\alpha=0.05$ was used for each comparison. Similar methodology was used to compare tick numbers (both questing and parasitic) between years. The Kruskal-Wallis test was conducted to determine general fluctuations. Wilcoxon tests were used for pairwise year comparisons. To control the overall significance level of $\alpha=0.05$ Bonferroni-Holm adjustment for $p$-values was applied (Holm 1979). Spearman correlation coefficients (Dohoo, Martin \& Stryhn 2010) were calculated to determine the relationship between questing and parasitic tick numbers, and monthly and annual rainfall.

\section{Results \\ Climate}

Maximum and minimum atmospheric temperatures, annual rainfall and relative humidity are graphically illustrated in Figure $1 \mathrm{a}, \mathrm{b}$ and $\mathrm{c}$. The highest mean temperatures were recorded during each February of the survey, whilst the lowest were recorded in various months between May and September. High maximum temperatures were sustained for six months during the summer of 2008/2009. Most rain fell during the period October-March, with a marked decrease in precipitation in 2009. Relative humidity was generally the lowest during the mid-winter months of June and July and highest from early to late summer (October or November to March or April).

\section{Questing ticks}

The species and total numbers of questing ticks collected from the vegetation at Döhne and Campagna are summarised in Table 1. Ten tick species were collected from the vegetation and the total number of questing larvae collected from the pastures grazed by Bonsmara cattle at Döhne was significantly different from the number collected from the pastures grazed 


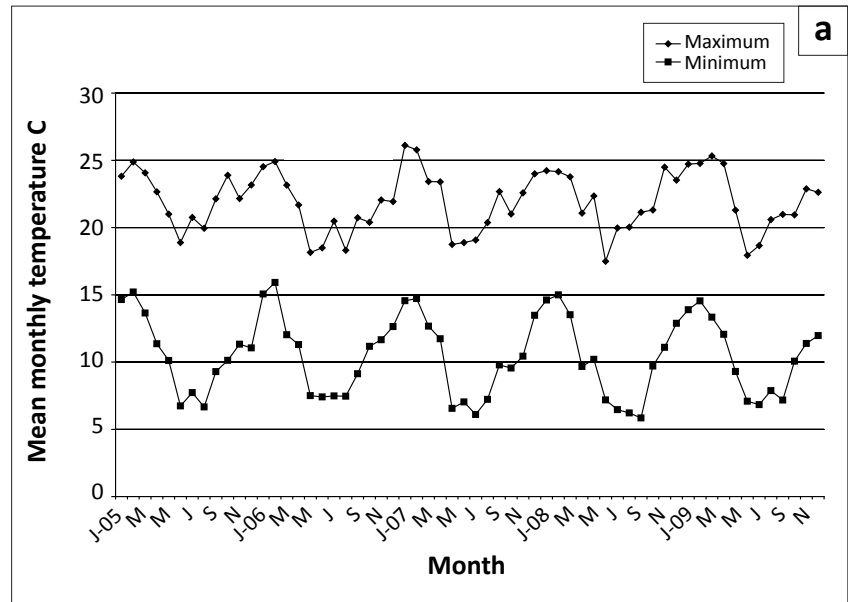

b
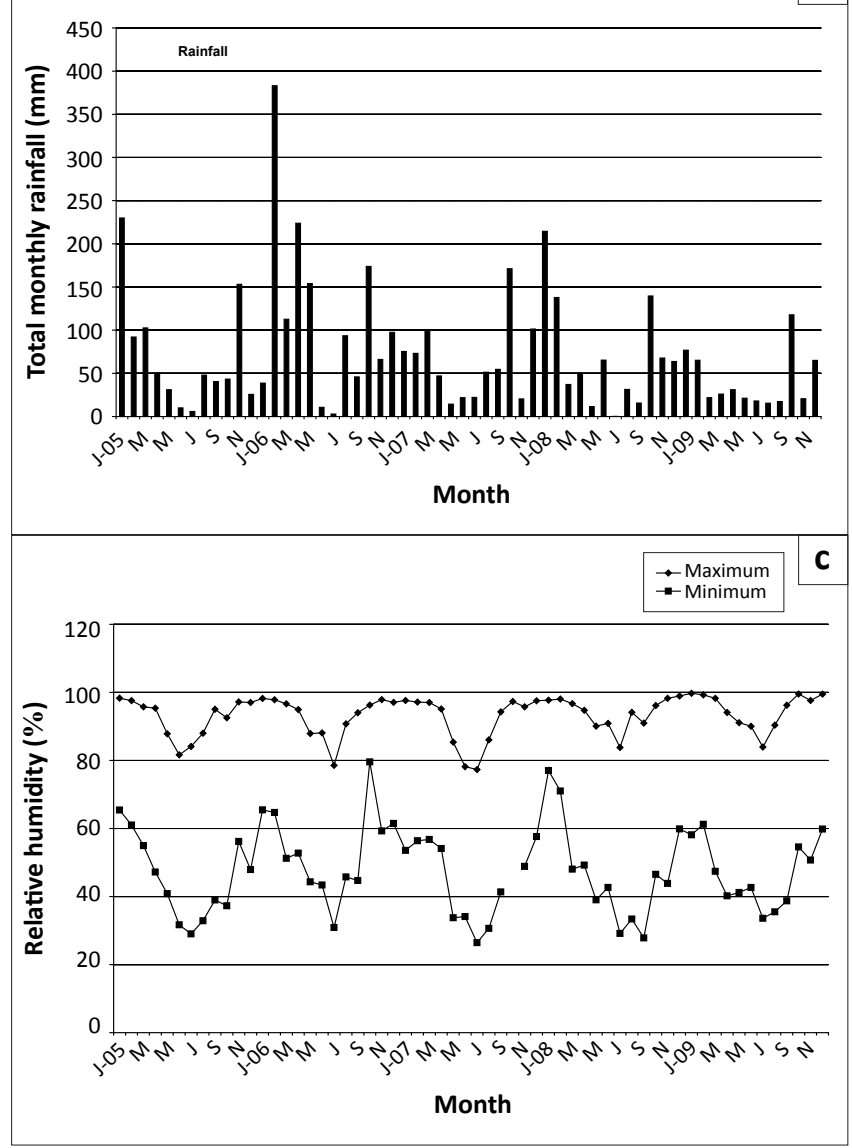

FIGURE 1: (a) Mean monthly maximum and minimum temperatures, (b) monthly rainfall and (c) mean monthly relative humidity at Döhne. by Nguni cattle $(p<0.001)$. The numbers of R. appendiculatus, $R$. decoloratus, Rhipicephalus evertsi evertsi and R. microplus larvae collected from the pastures grazed by Bonsmara cattle at Döhne were significantly different from those collected from pastures grazed by Nguni cattle $(p \leq 0.05)$. In all cases the tick counts associated with Bonsmara cattle were larger. The numbers of $R$. appendiculatus, $R$. decoloratus and $R$. microplus larvae collected from the pastures grazed by Bonsmara cattle at Döhne were also significantly greater than those collected from the pastures at Campagna $(p \leq 0.05)$.

The numbers of larvae of the five major tick species collected annually from the pastures at Döhne and Campagna are summarised in Table 2. During one or more years of the survey the annual total numbers of larvae of each of these species exhibited significant fluctuations $(p \leq 0.05)$ when compared with the numbers collected in any other year. Only one $A$. hebraeum larva was recovered during the first three years of the survey, but numbers increased substantially thereafter. The number of $R$. appendiculatus larvae collected during 2007 was substantially lower than in the previous years, but increased thereafter, whereas its nymphs and the larvae of $R$. evertsi evertsi exhibited a decreasing trend during the study period. Significantly fewer $R$. decoloratus larvae were collected during 2006 than in any other year of the survey, whilst slight annual fluctuations in the numbers of $R$. microplus larvae were observed.

Questing R. appendiculatus larvae reached peak numbers in April, followed by a smaller peak in August. Nymphs peaked in October (Figure 2a). Larvae of R. decoloratus and R. microplus were most abundant during August (Figure 2b), whilst $R$. evertsi evertsi larvae were most abundant during January, with successively smaller peaks in June and November, respectively (Figure 2c). The total numbers of $R$. evertsi evertsi larvae collected during each year of the survey appeared to be positively but not significantly $(p=0.5)$ correlated with annual rainfall (Figure 3). It should be noted, however, that this calculation was based on only five observations.

\section{Parasitic ticks}

The species and numbers of ticks collected from the cattle at Döhne and Campagna are summarised in Table 3. Adult ticks belonging to 12 species were collected and the total number

TABLE 1: Species composition of ticks questing for hosts from the pastures grazed by Bonsmara or Nguni cattle at Döhne or by Bonsmara cattle at Campagna (2005-2009).

\begin{tabular}{|c|c|c|c|c|c|c|c|}
\hline \multirow[t]{2}{*}{ Tick species } & \multicolumn{4}{|c|}{ Total number of questing ticks collected } & \multicolumn{3}{|c|}{ Number of questing larvae from each pasture } \\
\hline & LL & NN & MM & $\mathrm{FF}$ & Döhne: Bonsmara pastures & Döhne: Nguni pastures & Campagna: Bonsmara pastures \\
\hline Amblyomma hebraeum & 120 & 0 & 0 & 0 & $42(23)^{a}$ & $40(24)^{a}$ & $38(27)^{a}$ \\
\hline Haemaphysalis aciculifer & 15 & 0 & 0 & 0 & $5(3)$ & $1(1)$ & $9(5)$ \\
\hline Haemaphysalis elliptica & 6 & 1 & 0 & 1 & $2(2)$ & $2(2)$ & $2(2)$ \\
\hline Hyalomma rufipes & 3 & 0 & 0 & 0 & $0(0)$ & $0(0)$ & $3(3)$ \\
\hline Ixodes pilosus group & 1 & 1 & 0 & 0 & $0(0)$ & $1(1)$ & $0(0)$ \\
\hline Rhipicephalus appendiculatus & 774 & 117 & 0 & 0 & $346(106)^{c}$ & $204(82)^{a}$ & $224(78)^{b}$ \\
\hline Rhipicephalus decoloratus & 897 & 0 & 1 & 0 & $412(144)^{b}$ & $189(115)^{a}$ & $296(128)^{a}$ \\
\hline Rhipicephalus follis & 8 & 0 & 0 & 0 & $1(1)$ & $5(5)$ & $2(2)$ \\
\hline Rhipicephalus microplus & 3955 & 0 & 11 & 0 & $2017(297)^{c}$ & $733(221)^{\mathrm{a}}$ & $1205(273)^{\mathrm{b}}$ \\
\hline Total & 6532 & 119 & 13 & 2 & 3150 & 1334 & 2048 \\
\hline
\end{tabular}

$a, b, c$, Different superscripts represent significant differences amongst groups within each tick species $(p \geq 0.05)$.

Number of collections shown in brackets.

$\mathrm{LL}$, larvae; NN, nymphs; MM, males; FF, females. 
TABLE 2: Questing immature ticks of the five major species on the pastures at Döhne and Campagna during each year of the survey (2005-2009).

\begin{tabular}{|c|c|c|c|c|c|c|}
\hline \multirow[t]{3}{*}{ Year } & \multicolumn{6}{|c|}{ Number of questing ticks from the pastures at Döhne and Campagna } \\
\hline & \multirow{2}{*}{$\begin{array}{c}\text { Amblyomma } \\
\text { hebraeum } \\
\text { Larvae } \dagger\end{array}$} & \multicolumn{2}{|c|}{$\begin{array}{l}\text { Rhipicephalus } \\
\text { appendiculatus }\end{array}$} & \multirow{2}{*}{$\begin{array}{c}\text { Rhipicephalus } \\
\text { decoloratus } \\
\text { Larvae } \dagger\end{array}$} & \multirow{2}{*}{$\begin{array}{c}\text { Rhipicephalus } \\
\text { evertsi evertsi } \\
\text { Larvae } \dagger\end{array}$} & \multirow{2}{*}{$\begin{array}{c}\text { Rhipicephalus } \\
\text { microplus } \\
\text { Larvae } \dagger\end{array}$} \\
\hline & & Larvae $\dagger$ & Nymphs† & & & \\
\hline 2005 & $0(0)^{\mathrm{a}}$ & $113(43)^{\mathrm{a}}$ & $85(18)^{a}$ & $238(87)^{\mathrm{a}}$ & $224(88)^{a}$ & $985(127)^{\mathrm{a}}$ \\
\hline 2006 & $1(1)^{\mathrm{a}}$ & $275(69)^{b}$ & $15(13)^{\mathrm{a}}$ & $37(27)^{b}$ & $309(61)^{\mathrm{a}}$ & $670(148)^{\mathrm{a}, \mathrm{b}}$ \\
\hline 2007 & $0(0)^{\mathrm{a}}$ & $28(21)^{c}$ & $14(11)^{\mathrm{a}}$ & $255(103)^{\mathrm{a}}$ & $87(41)^{b}$ & $775(162)^{a, b}$ \\
\hline 2008 & $70(47)^{\mathrm{b}}$ & $205(73)^{b}$ & $1(1)^{b}$ & $151(83)^{\mathrm{a}}$ & $53(36)^{b}$ & $603(174)^{a, b}$ \\
\hline
\end{tabular}

$\dagger$, Significant fluctuation over years $(\alpha=0.05)$.

$a, b, c$, Years with the same letter were not significantly different according to the Bonferroni-Holm adjustment for $p$-values (global significance level $\alpha=0.05$ ). Number of collections shown in brackets.
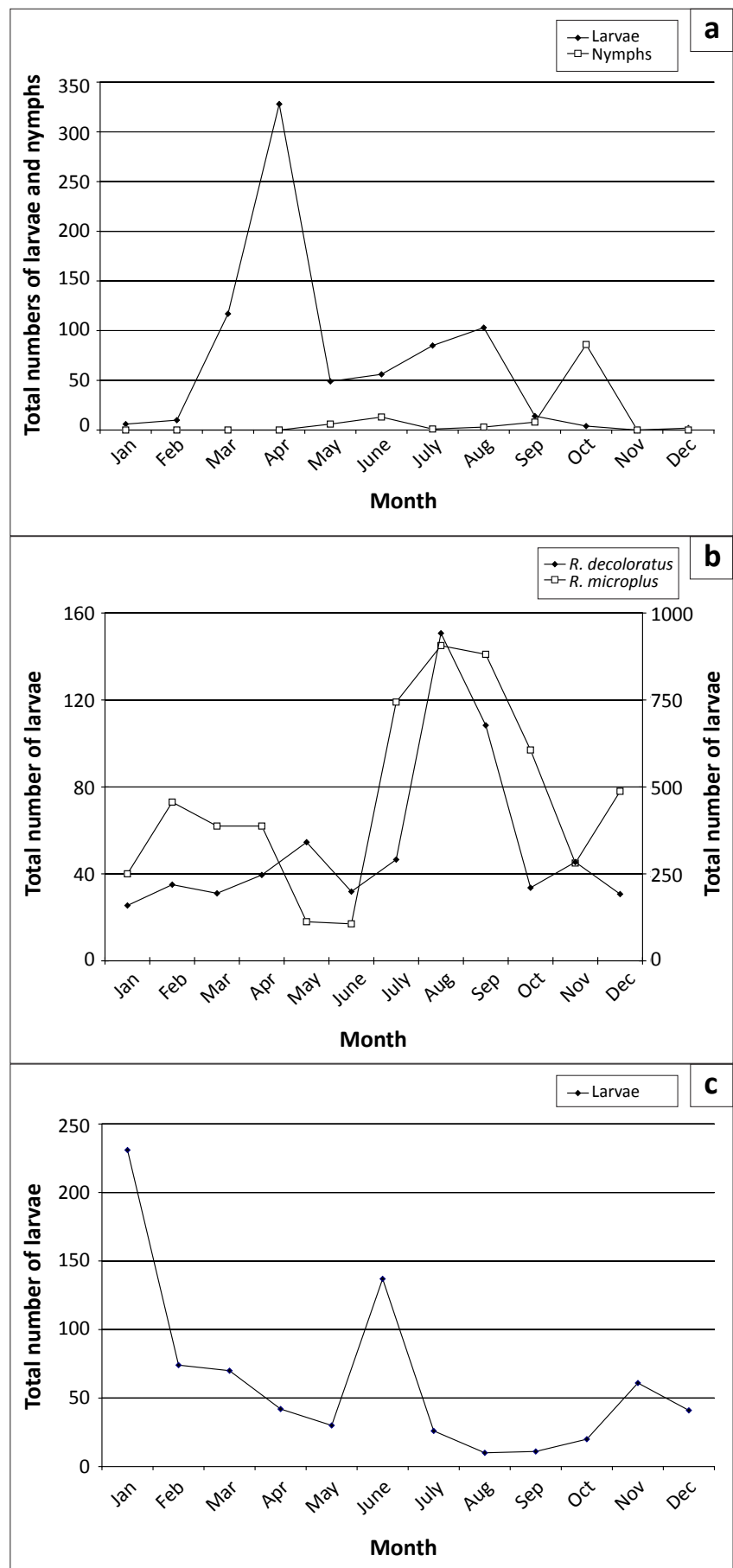

FIGURE 2: Composite seasonal abundance of questing (a) Rhipicephalus appendiculatus larvae and nymphs, (b) Rhipicephalus decoloratus and Rhipicephalus microplus larvae, and (c) Rhipicephalus evertsi evertsi larvae on the pastures at Döhne and Campagna (2005-2009). of ticks collected from Bonsmara cattle at Döhne significantly exceeded the number collected from Nguni cattle $(p<0.001)$. Greater numbers of $R$. appendiculatus, $R$. decoloratus, R. evertsi evertsi, Rhipicephalus follis and R. microplus were collected from the Bonsmara cattle at Döhne than from the Nguni cattle $(p \leq 0.05)$. A. hebraeum was collected only from the Bonsmara cattle at Campagna and these animals also harboured the vast majority of Hyalomma rufipes. Bonsmara cattle at Döhne carried significantly fewer $H$. rufipes and significantly more R. microplus than Bonsmara cattle at Campagna ( $p \leq 0.05)$.

The total numbers of ticks of the seven most abundant species collected annually from the Bonsmara and Nguni cattle at Döhne and the Bonsmara cattle at Campagna are summarised in Table 4. Only two A. hebraeum adults were collected in 2007, but considerably more were collected in 2008 and 2009. The numbers of $H$. rufipes and $R$. microplus fluctuated only slightly (but not significantly) during the three years of the study, whereas significant annual differences were observed in the numbers of the remaining tick species. Moreover, $R$. evertsi evertsi showed a significant increase and R. follis a significant decrease in numbers. The increase in annual numbers of adult $R$. evertsi evertsi seemed to be marginally inversely correlated with annual rainfall (Figure 4), with a correlation coefficient of -0.50 for aggregated yearly rainfall and -0.01 for monthly rainfall data. The correlations were, however, not significant. The decrease in annual numbers of $R$. follis seemed to be marginally positively correlated with annual rainfall (Figure 4), with a correlation coefficient of 0.50 for aggregated yearly rainfall and 0.29 for monthly rainfall. Also these correlations proved to be non-significant.

The seasonal abundances of the six most numerous tick species collected from the cattle at Döhne and Campagna are graphically illustrated in Figure 5. Adult H. rufipes reached peak numbers in midsummer and late summer, whilst $R$. appendiculatus numbers peaked in spring and late summer (Figure 5a). The numbers of $R$. decoloratus and $R$. microplus declined erratically from January to August, increased in September and declined towards November, followed by a marked increase in December (Figure 5b). The greatest numbers of $R$. evertsi evertsi were present from January to March and in September and the fewest from May to August, whereas most $R$. follis were collected during August (Figure 5c). 


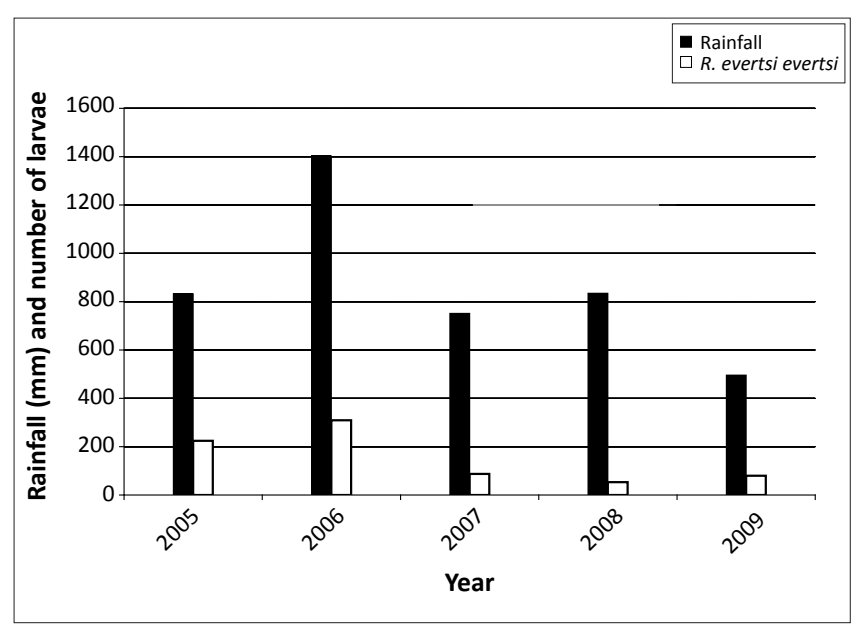

FIGURE 3: Annual rainfall and numbers of questing Rhipicephalus evertsi evertsi larvae collected at Döhne and Campagna (2005-2009).

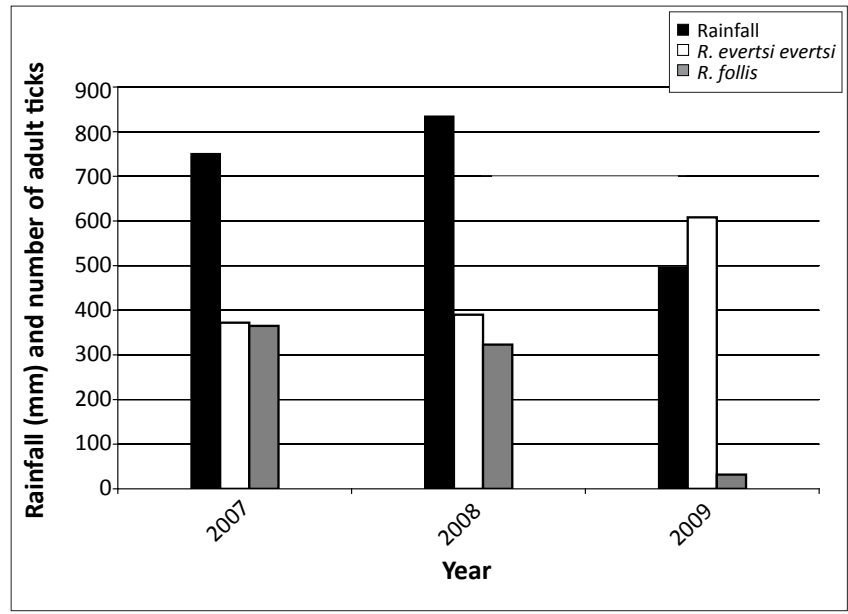

FIGURE 4: Annual rainfall and numbers of adult Rhipicephalus evertsi evertsi and Rhipicephalus follis on cattle at Döhne and Campagna (February 2007 - January 2010).

TABLE 3: Adult ticks collected from Bonsmara and Nguni cattle at Döhne, and Bonsmara cattle at Campagna (February 2007 to January 2010 ).

\begin{tabular}{|c|c|c|c|c|c|}
\hline \multirow[t]{2}{*}{ Tick species } & \multicolumn{2}{|c|}{ Total number of adult ticks collected } & \multicolumn{3}{|c|}{ Number of adult ticks from each breed } \\
\hline & Males & Females & Bonsmara Döhne & Nguni Döhne & Bonsmara Campagna \\
\hline Amblyomma hebraeum & 45 & 16 & $0(0)$ & $0(0)$ & $61(14)$ \\
\hline Haemaphysalis elliptica & 0 & 1 & $0(0)$ & $1(1)$ & $0(0)$ \\
\hline Haemaphysalis silacea & 0 & 2 & $1(1)$ & $1(1)$ & $0(0)$ \\
\hline Hyalomma rufipes & 120 & 72 & $7(7)^{\mathrm{b}}$ & $0(0)^{\mathrm{a}}$ & $185(46)^{c}$ \\
\hline Ixodes pilosus group & 0 & 4 & $1(1)$ & $0(0)$ & $3(3)$ \\
\hline Rhipicephalus appendiculatus & 187 & 120 & $147(30)^{\mathrm{b}}$ & $21(13)^{\mathrm{a}}$ & $139(31)^{\mathrm{b}}$ \\
\hline Rhipicephalus decoloratus & 67 & 362 & $190(57)^{\mathrm{b}}$ & $25(18)^{a}$ & $214(46)^{b}$ \\
\hline Rhipicephalus evertsi evertsi & 989 & 381 & $560(90)^{\mathrm{b}}$ & $161(66)^{\mathrm{a}}$ & $649(95)^{\mathrm{b}}$ \\
\hline Rhipicephalus follis & 385 & 335 & $308(57)^{\mathrm{b}}$ & $103(37)^{\mathrm{a}}$ & $309(59)^{b}$ \\
\hline Rhipicephalus lounsburyi & 5 & 0 & $4(4)$ & $0(0)$ & $1(1)$ \\
\hline Rhipicephalus microplus & 23 & 401 & $214(74)^{c}$ & $65(37)^{a}$ & $145(54)^{b}$ \\
\hline Rhipicephalus simus & 8 & 8 & $6(5)$ & $3(3)$ & $7(6)$ \\
\hline Total & 1829 & 1702 & 1438 & 380 & 1713 \\
\hline
\end{tabular}

$a, b, c$, Different superscripts represent significant differences amongst groups within each tick species $(\alpha=0.05)$.

Number of collections shown in brackets.

TABLE 4: Number of adult ticks collected during each 12-month period from six Bonsmara cattle and three Nguni cattle (February 2007 to January 2010).

\begin{tabular}{|c|c|c|c|c|c|c|c|}
\hline \multirow[t]{2}{*}{ Year } & \multicolumn{7}{|c|}{ Total number of adult ticks collected } \\
\hline & $\begin{array}{c}\text { Amblyomma } \\
\text { hebraeum } \dagger\end{array}$ & $\begin{array}{l}\text { Hyalomma } \\
\text { rufipes }\end{array}$ & $\begin{array}{c}\text { Rhipicephalus } \\
\text { appendiculatus } \dagger\end{array}$ & $\begin{array}{l}\text { Rhipicephalus } \\
\text { decoloratus } \dagger\end{array}$ & $\begin{array}{c}\text { Rhipicephalus } \\
\text { evertsi evertsi } \dagger\end{array}$ & $\begin{array}{l}\text { Rhipicephalus } \\
\text { follis }{ }^{\dagger}\end{array}$ & $\begin{array}{c}\text { Rhipicephalus } \\
\text { microplus }\end{array}$ \\
\hline 2007 & $2^{\mathrm{a}}$ & $72^{\mathrm{a}}$ & $149^{\mathrm{a}}$ & $213^{\mathrm{a}}$ & $372^{\mathrm{a}}$ & $365^{\mathrm{a}}$ & $159^{\mathrm{a}}$ \\
\hline 2009 & $23 a^{b}$ & $61^{\mathrm{a}}$ & $110^{\mathrm{a}, \mathrm{b}}$ & $122^{a, b}$ & $608^{b}$ & $32^{\mathrm{b}}$ & $142^{\mathrm{a}}$ \\
\hline
\end{tabular}

$\dagger$, Significant fluctuation over years $(\alpha=0.05)$.

$\mathrm{a}, \mathrm{b}$, Years with the same letter were not significantly different according to Bonferroni-Holm adjustment for $p$-values (global significance level $\alpha=0.05$ ).

\section{Discussion}

\section{General}

Rechav (1987) and Rechav, Dauth and Els (1990) have demonstrated that under field conditions in South Africa, Brahman cattle are more resistant to tick infestation than Hereford or Simmentaler cattle. Spickett et al. (1989) have shown that Nguni cattle are more resistant to natural tick challenge than Bonsmara or Hereford cattle and Rechav and Kostrzewski (1991) have reported that Nguni cattle were more resistant to infestation by $R$. decoloratus than the five other breeds of cattle in their study. Despite the fact that the Bonsmara cattle in the present study were regularly treated with an acaricide, and the Nguni cattle only when adult ticks became visible, the Bonsmara cattle harboured significantly greater numbers of adult ticks than the Nguni cattle, confirming the findings of Spickett et al. (1989). The larger numbers of questing larvae recovered from the pastures grazed by Bonsmara cattle can thus be construed as a consequence of the greater number of adult ticks on these animals when compared with the numbers of larvae on the pastures grazed by Nguni cattle.

The small numbers of questing ticks collected from the vegetation and parasitic ticks from cattle are probably a consequence of the regular application of acaricides to cattle at Döhne and Campagna. Despite these small numbers, a total of 13 species were represented. In comparison, only six 

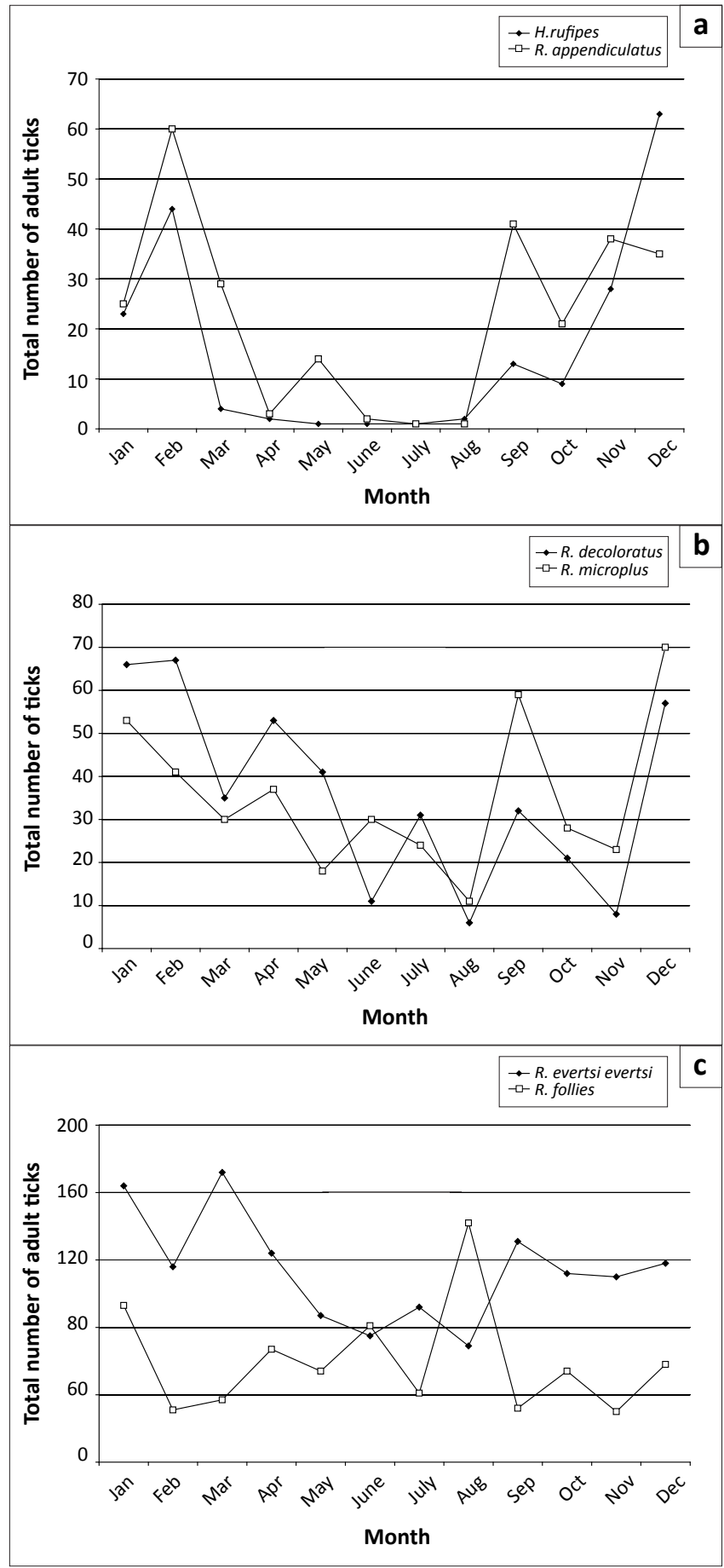

FIGURE 5: Composite seasonal abundance of adult (a) Hyalomma rufipes and Rhipicephalus appendiculatus, (b) Rhipicephalus decoloratus and Rhipicephalus microplus, and (c) Rhipicephalus evertsi evertsi and Rhipicephalus follis on cattle at Döhne and Campagna (February 2007 - January 2010).

ixodid tick species were collected during 2004 and 2005 from vegetation and cattle at 72 dip-tanks in rural farming areas east of Döhne (Horak et al. 2009). Although the number of ticks collected at each occasion in the present study was low, aggregate monthly and annual trends could be determined because the survey was conducted over several years.

The immature stages of Haemaphysalis elliptica, R. follis and Rhipicephalus simus all use rodents as hosts (Petney et al. 2004) and H. rufipes use hares and birds (Horak \& Fourie
1991; Van Niekerk, Fourie \& Horak 2006). Adult H. elliptica use carnivores and large felids as hosts and the adults of the other three ticks use cattle and other large hosts. Engorged female ticks detach from these hosts wherever they may roam, feed or rest, and then seek out a sheltered environment to lay their eggs. Very few larvae of these species are usually collected from the vegetation and in the absence of another explanation it must be assumed that they quest for their small mammal hosts from the soil surface or from the base of the vegetation.

\section{Amblyomma hebraeum}

The first appearance of an A. hebraeum larva on the pastures in 2006 and the presence of a small number of adult ticks on cattle in 2007 may be the result of the introduction of engorged immature ticks on birds, particularly helmeted guineafowls and francolins, from neighbouring farms. These birds may harbour exceptionally large numbers of A. hebraeum larvae and lesser numbers of nymphs (Horak et al. 1991a; Uys \& Horak 2005).

The long-term (1969-2001) mean annual rainfall at Döhne is $773 \mathrm{~mm}$, although, with the exception of 1992 when only $382 \mathrm{~mm}$ was recorded, the $490 \mathrm{~mm}$ recorded in 2009 is the lowest for the past 40 years. Estrada-Peña, Horak and Petney (2008) noted that more intense periods of drought in the highveld of Zimbabwe may lead to an expansion of the distribution of $A$. hebraeum in this region, whereas increased temperatures may have the same consequence in the lowveld. The treed-savanna habitat at Campagna constitutes a suitable vegetational environment for all stages of development of A. hebraeum. Moreover, the lower than normal rainfall in the last year of the study, coupled with sustained high summer temperatures, may have contributed to an optimal environment in which a small existing population of ticks could flourish or in which introduced ticks could become established.

Larvae and adult ticks were collected from the vegetation and cattle at Campagna, but only larvae were collected from the pastures at Döhne. Howell, Walker and Nevill (1978) state that $A$. hebraeum cannot survive in open grasslands, and Horak, Gallivan and Spickett (2011) collected fewest questing A. hebraeum larvae from grasslands compared to woodlands and gullies in a treed savanna locality in the Kruger National Park. The open grass pastures at Döhne would thus seem unlikely to sustain A. hebraeum; nevertheless, some ticks must have completed their life cycles there, hence the presence of questing larvae.

\section{Hyalomma rufipes}

This is a two-host tick and its immature stages infest hares and ground-feeding birds (Horak \& Fourie 1991; Van Niekerk et al. 2006). Because most larvae are likely to quest for their relatively small hosts from the soil surface, few were collected by dragging. Campagna provided a suitable environment for all stages of development of $H$. rufipes, whereas the open 
pastures of Döhne did not. The small number of adult ticks collected from Bonsmara cattle at Döhne each year could represent an existing population or be the consequence of engorged nymphs transported there on birds. The summer abundance of adult $H$. rufipes agrees with that observed on cattle in Limpopo province and in the south-western Free State (Fourie \& Horak 1990; Schröder 1980).

\section{Rhipicephalus appendiculatus}

$R$. appendiculatus is a three-host species, which, in South Africa, completes a single life cycle annually. In Valley Bushveld, approximately $60 \mathrm{~km}$ south-west of Döhne, larvae of $R$. appendiculatus were most abundant on cattle and kudus from late summer to mid-winter, whilst nymphs were found in spring and adults from early to late summer (Horak et al. 1992; Horak 1999). This pattern of seasonality is not unlike that observed for free-living larvae and nymphs on the pastures and parasitic adult ticks on the cattle at the Döhne complex.

Theiler (1962) stated that R. appendiculatus is consistently absent in open grasslands, whilst Short et al. (1989) reported reduced survival of the free-living stages of $R$. appendiculatus in short grass habitats in Zimbabwe. This does not appear to be the case at the Döhne complex, where slightly more $R$. appendiculatus larvae were collected from the open grass pastures and adult ticks from the Bonsmara cattle at Döhne than from the vegetation and cattle in the treed savanna habitat of Campagna.

\section{Rhipicephalus decoloratus}

$R$. decoloratus is a one-host species and consequently only larvae are expected to quest for hosts from the vegetation; however, a single male was also collected from a drag sample. This phenomenon will be discussed in greater detail for $R$. microplus. The spring rise in the number of questing larvae, accompanied by an increase in the number of adult ticks, would appear to be the impetus required to maintain the parasitic life cycle for the remainder of the year. The decline in numbers in the late summer probably results from resistance to infestation acquired by the cattle and hence fewer females detaching and laying eggs, thus resulting in fewer questing larvae. Similar findings on questing larvae have been recorded at two localities in the Kruger National Park (Horak et al. 2011).

\section{Rhipicephalus evertsi evertsi}

$R$. evertsi evertsi is a two-host tick with one of the most widespread distributions of any tick species in sub-Saharan Africa (Walker, Keirans \& Horak 2000). With the exception of the arid Northern Cape province and northern Western Cape province it is present throughout South Africa (Howell et al. 1978). In an open, treed savanna in the south of the Kruger National Park, most $R$. evertsi evertsi larvae were collected in grassland compared to woodland and gully habitats (Gallivan et al. 2011). It infests all domestic and wild bovids and equids, with hares also being effective hosts of the immature stages (Walker et al. 2000). Despite the species' widespread distribution and extensive host range, adult ticks are never recovered in large numbers.

R. evertsi evertsi can complete more than one life cycle annually and thus more than one peak in the abundance of immature and adult ticks can occur in a single year. The pattern of summer, winter and spring peaks in the numbers of questing larvae collected from the pastures at Döhne (Figure 5c) is similar to that found for ticks on sheep on a highveld farm in the eastern Free State (Horak, Williams \& Van Schalkwyk 1991b). The decrease in numbers of questing larvae on the pastures at Döhne with decreasing rainfall, whilst the numbers of adult ticks on cattle increased is difficult to explain.

\section{Rhipicephalus follis}

This tick has a strictly South African distribution and occurs in hilly or mountainous terrain in the east of the country, from the southern and south-eastern coastal regions to the escarpment in the Mpumalanga province (Walker et al. 2000). The adults prefer large herbivorous animals as hosts, whilst the immature stages prefer murid rodents. Large numbers of adult ticks have been collected from elands in the Mountain Zebra National Park near Cradock (Horak et al. 1991c), and immature ticks from four-striped mice in the Thomas Baines Reserve near Grahamstown (Petney et al. 2004). Adult ticks appear to be present throughout the year (Figure 5c), as also found by Horak et al. (1991c). Few larvae were collected from the vegetation, probably because they quest for their murid rodent hosts from the soil surface or from the base of the vegetation. The decrease in numbers of $R$. follis adults over time was probably associated with a decrease in rodent populations during a period of below-average rainfall.

\section{Rhipicephalus microplus}

One of the first documented records of R. microplus in South Africa is that made by Howard (1908). He referred to it as Margaropus annulatus australis, but his illustrations clearly depict $R$. microplus. Howard recorded the species' presence at King William's Town (approximately $50 \mathrm{~km}$ south-east of Döhne) and in the southern districts of the Cape Colony. Theiler (1962) cites Dönitz as stating that this species (as Boophilus annulatus) seems to be displacing $R$. decoloratus in South Africa inland from the coast. The distribution of $R$. microplus described by Howell et al. (1978) is discontinuous and extends from the southern regions of the Western Cape province along the coast and adjacent inland regions to north-eastern KwaZulu-Natal, with scattered localities in the northern provinces. Since then its distribution has expanded remarkably, usually at the expense of $R$. decoloratus, and this phenomenon has been particularly noticeable in the eastern region of the Eastern Cape province (Horak et al. 2009). Reasons for this displacement have been suggested by Horak et al. (2009). Both species are, however, present at Döhne and although $R$. microplus is predominant, $R$. decoloratus appears to have maintained its status over the past five years. 
Theoretically, only larvae of this one-host tick should quest for hosts from the vegetation. However, 11 male ticks were also collected from the drag cloths, implying that they must have detached shortly before or after moulting and were now questing from the vegetation for a second host. Mason and Norval (1981) mention that Norval (unpublished data) had collected adult male ticks from drag samples and they then demonstrated that larvae and adult males of $R$. microplus could transfer from infested to uninfested cattle under field conditions. Larvae of $R$. microplus were the most numerous of all species collected from the vegetation at the Döhne complex and significantly greater numbers $(p<0.001)$ were collected from the pastures grazed by Bonsmara cattle than from those grazed by Nguni cattle. Similarly, the numbers of adult ticks collected from the Bonsmara cattle differed significantly $(p<0.001)$ from those collected from the Nguni cattle.

\section{Less commonly collected species}

Haemaphysalis aciculifer is present in patches along the southeastern, southern and eastern coastline and adjacent inland regions of South Africa. Its immature stages infest rodents and birds and its adults infest various antelope species (Horak \& Boomker 1998). H. elliptica, previously referred to as Haemaphysalis leachi, parasitises domestic dogs and cats and the larger wild felids (Apanaskevich, Horak \& Camicas 2007) and its presence on the pastures and cattle in this study are probably a consequence of the odd dog or feral cat traversing the camps. Haemaphysalis silacea is essentially a tick of the Valley Bushveld and surrounding well-wooded regions of the Eastern Cape province, where all stages parasitise kudus and cattle (Horak et al. 1992; Horak 1999). The few ticks collected at Döhne probably represent an eastern fringe of its distribution. Ticks of the Ixodes pilosus group are present along the south-western coast and adjacent areas of the Western and Eastern Cape provinces, extending to the southern coastal and adjacent inland regions of KwaZulu-Natal (Howell et al. 1978). Rhipicephalus lounsburyi is a strictly South African species and is present in the more mountainous and hilly regions of the Eastern Cape province (Walker et al. 2000). The geographic distribution of $R$. simus is more extensive than that of $R$. follis and although their distributions overlap (Walker et al. 2000), one or the other is usually more numerous at a particular locality, depending on the environment.

\section{Conclusion}

At a locality in the Eastern Cape province, South Africa, where 13 species of ixodid ticks were present, Nguni cattle proved to be less susceptible to infestation with adult ticks than Bonsmara cattle. Fewer questing ticks were also collected from pastures grazed by Nguni cattle than from those grazed by Bonsmara cattle.

\section{Acknowledgements}

We thank the Eastern Cape Department of Agriculture for permission to conduct the study at Döhne and Campagna and for approving the participation of Messrs Nyangiwe and Goni in the project. Ritha Wentzel of the Agricultural Research Council kindly provided us with the climatological data. The study was funded by the University of Pretoria, Bayer Animal Health, the National Research Foundation and the Institute for Tropical Medicine, Belgium.

\section{Authors' contributions}

N.N. and I.G.H. planned the survey; N.N. was the project leader and collected the ticks and assisted with the manuscript; S.G. assisted N.N. with the tick collections; L.P.H-C. and I.R. performed statistical calculations and wrote the statistical part of the manuscript; I.G.H. identified the ticks and wrote the manuscript.

\section{References}

Acocks, J.P.H., 1988, Veld types of South Africa with accompanying veld type map, 3rd edn., Botanical Research Institute, Department of Agriculture, Pretoria.

Altman, D.G., 1991, Practical statistics for medical research, Chapman \& Hall, London.

Apanaskevich, D.A., Horak, I.G. \& Camicas, J.-L., 2007, 'Redescription of Haemaphysalis (Rhipistoma) elliptica (Koch, 1844), an old taxon of the Haemaphysalis (Rhipistoma) leachi group from East and southern Africa, and of Haemaphysalis (Rhipistoma) leachi (Audouin, 1826) (Ixodida, Ixodidae)', Onderstepoort Journal of Veterinary Research 74, 181-207. PMid:17933361

Dohoo, I., Martin, W. \& Stryhn, H., 2009, Veterinary epidemiologic research, University of Prince Edward Island, Charlottetown.

Estrada-Peña, A., Horak, I.G. \& Petney, T.N., 2008, 'Changes in climate and their suitability for the ticks Amblyomma hebraeum and Amblyomma variegatum (Ixodidae) in Zimbabwe (1974-1999)', Veterinary Parasitology 151, 256-267. doi:10.1016/j.vetpar.2007.11.014, PMid:18083309

Fourie, L.J. \& Horak, I.G., 1990, 'Parasites of cattle in the south western Orange Free State', Journal of the South African Veterinary Association 61, 27-28. PMid:2269986

Gallivan, G.J., Spickett, A., Heyne, H., Spickett, A.M. \& Horak, I.G., 2011, 'The dynamics of questing ticks collected for 164 consecutive months off the vegetation of two landscape zones in the Kruger National Park (1988-2002). Part III. The less commonly collected species', Onderstepoort Journal of Veterinary Research 78(1), Art. \#41, 9 pages. doi:10.4102/ojvr.v78i1.41

Holm, S., 1979, 'A simple sequentially rejective multiple test procedure', Scandinavian Journal of Statistics 6, 65-70.

Hoogstraal, H., 1956, African Ixodoidea. I. Ticks of the Sudan (with special reference to Equatoria Province and with preliminary reviews of the genera Boophilus, Margaropus and Hyalomma). Research Report NM 005.050.29.07, Department of the Navy, Bureau of Medicine and Surgery, Washington DC.

Horak, I.G. \& Fourie, L.J., 1991, 'Parasites of domestic and wild animals in South Africa. XXIX. Ixodid ticks on hares in the Cape Province and on hares and red rock rabbits in the Orange Free State', Onderstepoort Journal of Veterinary Research 58, 261270. PMid:1780126

Horak, I.G., Spickett, A.M., Braack, L.E.O. \& Williams, E.J., 1991a, 'Parasites of domestic and wild animals in South Africa. XXVII. Ticks on helmeted guineafowls in the eastern Cape Province and eastern Transvaal Lowveld', Onderstepoort Journal of Veterinary Research 58, 137-143. PMid:1923375

Horak, I.G., Williams, E.J. \& Van Schalkwyk, P.C., 1991b, 'Parasites of domestic and wild animals in South Africa. XXV. Ixodid ticks on sheep in the north-eastern Orange Free State and in the eastern Cape Province', Onderstepoort Journal of Veterinary Research 58, 115-123. PMid:1923373

Horak, I.G., Fourie, L.J., Novellie, P.A. \& Williams, E.J., 1991c, 'Parasites of domestic and wild animals in South Africa. XXVI. The mosaic of ixodid tick infestations on birds and mammals in the Mountain Zebra National Park', Onderstepoort Journal of Veterinary Research 58, 125-136. PMid:1923374

Horak, I.G., Boomker, J., Spickett, A.M. \& De Vos, V., 1992, 'Parasites of domestic and wild animals in South Africa. XXX. Ectoparasites of kudus in the eastern Transvaal Lowveld and the eastern Cape Province', Onderstepoort Journal of Veterinary Lowveld and the eastern Cape Provin
Research 59, 259-273. PMid:1297956

Horak, I.G. \& Boomker, J., 1998, 'Parasites of domestic and wild animals in South Africa. XXXV. Ixodid ticks and bot fly larvae in the Bontebok National Park', Onderstepoort Journal of Veterinary Research 65, 205-211. PMid:9809325

Horak, I.G., 1999, 'Parasites of domestic and wild animals in South Africa. XXXVII. Ixodid ticks on cattle on Kikuyu grass pastures and in Valley Bushveld in the Eastern Cape Province', Onderstepoort Journal of Veterinary Research 66, 175184. PMid:10631707

Horak, I.G., Nyangiwe, N., De Matos, C. \& Neves, L., 2009, 'Species composition and geographic distribution of ticks infesting cattle, goats and dogs in a temperate and a subtropical coastal region of south-eastern Africa', Onderstepoort Journal of Veterinary Research 76, 263-278. PMid:21105593 
Horak, I.G., Gallivan, G.J. \& Spickett, A.M., 2011, 'The dynamics of questing ticks collected for 164 consecutive months off the vegetation of two landscape zones
in the Kruger National Park (1988-2002). I. Total ticks, Amblyomma hebraeum and Rhipicephalus decoloratus', Onderstepoort Journal of Veterinary Research 78(1), Rhipicephalus decoloratus', Onderstepoort Jo
Art. \#32, 10 pages. doi:10.4102/ojvr.v78i1.32

Howard, C.W., 1908, 'A list of the ticks of South Africa, with descriptions and keys to all the forms known', Annals of the Transvaal Museum 1, 73-188.

Howell, C.J., Walker, J.B. \& Nevill, E.M., 1978, 'Ticks, mites and insects infesting domestic animals in South Africa, Part 1, Descriptions and biology', Science Bulletin, no. 393, Department of Agricultural Technical Services, South Africa.

Mason, C.A. \& Norval, R.A.I., 1981, 'The transfer of Boophilus microplus (Acarina, Ixodidae) from infested to uninfested cattle under field conditions', Veterinary Parasitology 8, 185-188. doi:10.1016/0304-4017(81)90046-7

Norval, R.A.I. \& Horak, I.G., 2004, 'Vectors: ticks', in J.A.W. Coetzer \& R.C. Tustin (eds.), Infectious diseases of livestock, pp. 3-42, Oxford University Press, Cape Town.

Petney, T.N., Horak, I.G., Howell, D.J. \& Meyer, S., 2004, 'Striped mice, Rhabdomys pumilio, and other murid rodents as hosts for immature ixodid ticks' pumilio, and other murid rodents as hosts for immature ixodid
Onderstepoort Journal of Veterinary Research 71, 313-318. PMid:15732458

Rechav, Y., 1987, 'Resistance of Brahman and Hereford cattle to African ticks with reference to serum gamma globulin levels and blood composition', Experimental and Applied Acarology 3, 219-232. doi:10.1007/BF01270458

Rechav, Y., Dauth, J. \& Els, D.A., 1990, 'Resistance of Brahman and Simmentaler cattle to southern African ticks', Onderstepoort Journal of Veterinary Research 57, 7-12. PMid:2339000

Rechav, Y. \& Kostrzewski, M.W., 1991, 'Relative resistance of six cattle breeds to the tick Boophilus decoloratus in South Africa', Onderstepoort Journal of Veterinary Research 58, 181-186. PMid:1923380
Schröder, J., 1980, 'Cattle ticks from the Waterberg District of the Transvaal', Journal of the South African Veterinary Association 51, 27-30. PMid:7452655

Short, N.J., Floyd, R.B., Norval, R.A.I. \& Sutherst, R.W., 1989, 'Survival and behaviour of the unfed stages of the ticks Rhipicephalus appendiculatus, Boophilus decoloratus and $B$. microplus under field conditions in Zimbabwe', Experimental and Applied Acarology 6, 215-236. doi:10.1007/BF01193981, doi:10.1007/BF01201643

Spickett, A.M., De Klerk, D., Enslin, C.B. \& Scholtz, M.M., 1989, 'Resistance of Nguni, Bonsmara and Hereford cattle to ticks in a Bushveld region of South Africa', Onderstepoort Journal of Veterinary Research 56, 245-250. PMid:2626263

Spickett, A.M., Horak, I.G., Van Niekerk, A. \& Braack, L.E.O., 1992, 'The effect of veldburning on the seasonal abundance of free-living ixodid ticks as determined by drag-sampling', Onderstepoort Journal of Veterinary Research 59, 285-292. PMid:1297958

Theiler, G., 1962, 'The Ixodoidea parasites of vertebrates in Africa south of the Sahara (Ethiopian Region)', Division of Veterinary Services, Onderstepoort (mimeographed).

Uys, A.C. \& Horak, I.G., 2005, 'Ticks on crested francolins, Francolinus sephaena, and on the vegetation on a farm in Limpopo Province, South Africa', Onderstepoort Journal of Veterinary Research 72, 339-343. PMid:16562738

Van Niekerk, J., Fourie, L.J. \& Horak, I.G., 2006, 'Birds as hosts of immature ixodid ticks in Free State Province, South Africa', Onderstepoort Journal of Veterinary Research 73, 123-130. PMid:16958263

Walker, J.B., 1991, 'A review of the ixodid ticks (Acari, Ixodidae) occurring in southern Africa', Onderstepoort Journal of Veterinary Research 58, 81-105. PMid:1881661

Walker, J.B., Keirans, J.E. \& Horak, I.G., 2000, The genus Rhipicephalus (Acari, Ixodidae): a guide to the brown ticks of the world, Cambridge University Press, Cambridge. 